\title{
EVALUATION OF SEMEN AND NON-RETURN RATE OF BULLS IN ARTIFICIAL INSEMINATION (AI) CENTER
}

\author{
S. Nasrin ${ }^{1}$, M. R. Amin ${ }^{1}$ and M. K. Alam ${ }^{2}$
}

\begin{abstract}
The experiment was conducted to evaluate the bull performance based on semen quality and 60 days non-return rate. Data were collected from 60 ejaculates and 525 services. Semen for insemination was used from bulls of different genetic groups (2 Holstein cross, 1 Sindhi cross, 1 Sahiwal cross and 1 Red Chittagong). Individual bull effect was found to be significant $(\mathrm{P}<0.01)$ on volume per ejaculate, mass motility, sperm concentration, live sperm and normal sperm percentage. The significantly $(\mathrm{P}<0.01)$ highest volume per ejaculate, sperm concentration, live sperm and normal percentage were found in Holstein cross and lowest in Red Chittagong Bull. Non-return rate was highest in Holstein cross bull and lowest in Red Chittagong Bull. Significant $(\mathrm{P}<0.01)$ positive correlation was observed in mass motility, live sperm and normal sperm percentage with non-return rate. It was concluded that Holstein cross Bull was the best among the bulls.
\end{abstract}

Key words : Semen parameter, Non-return rate, Cross-bred bulls

\section{Introduction}

Artificial Insemination (AI) is the most important single technique devised for rapid genetic improvement, economization of breeding program and control of venereal diseases of domestic animals. This is possible because a few highly selected male produce enough spermatozoa to inseminate thousands of females per year (Hafez, 1993). So, a bull is aptly said to be half of the herd. To select breeding bulls, evaluation of semen is of prime importance. The term 'quality of semen' encompasses motility (\%) of spermatozoa, concentration of spermatozoa, proportion of live and morphologically normal spermatozoa, seminal $\mathrm{pH}$ and optimum metabolic feature of individual sperm (Hoque, 1998). In order to evaluate the fertilizing capacity of semen sample a reasonable number of cows is to be inseminated and after 60 days the non-return rate of the cows can be calculated. The nonreturn rate of bulls depends on holistic semen characteristics of bull, breeding soundness of cows and appropriateness of time and site for semen deposition. The present study was therefore aimed to evaluate the semen quality of bulls used at Bangladesh Agricultural University AI center, to measure the degree of retrospective fertility interms of non-return

Corresponding author: Dr. M. R. Amin. E-mail: ruhulamin_bau@yahoo.com

${ }^{1}$ Department of Animal Breeding \& Genetics, Bangladesh Agricultural University, Mymensingh-2202, Bangladesh

${ }^{2}$ Scientific Officer, Red Chittagong Cattle Project, Bangladesh Livestock Research Institute, Savar, Dhaka, Bangladesh

(Received : June 23 2008) 
Bang. J. Anim. Sci. 2008, 37(2)

rate and also to establish the relationship between semen quality and non-return rate in AI bulls.

\section{Materials and Methods}

The present study was conducted at Bangladesh Agricultural University AI Center from 1 May to 31 October 2006. Experimental bulls were Holstein Friesian $\times$ Local (Bull No. 14), Local $\times$ Holstein Friesian (Bull No. 129), Sahiwal $\times$ Holstein $($ Bull No. 143), Sindhi $\times$ Local (Bull No. 122), Red Chittagong (Bull No. 41) and Red Chittagong (Bull No. 45). The age of the bulls were determined by the date of birth upto June, 2006 ranged from 36 to 90 months. Bulls were maintained under identical feeding (12-15\% of protein in the diet) and management system. The bulls were made sure of breeding soundness before bringing in use. Semen was collected from each bull twice a week. Evaluation of fresh semen was done immediately after collection using the method described by Herman and Madden (1963). The volume, color, density, mass motility (\%), sperm concentration (million/ml), live sperm count (\%), measurements of spermatozoa of individual bull were recorded. To observe the mass motility, one drop of semen was placed on a pre-warmed $\left(37^{\circ} \mathrm{C}\right)$ slide under microscope at 10x. Mass motility was scored into 0 to 5 scales according to Herman and Madden (1963). Sperm concentration was determined by using haemocytometer method. To measure live sperm count, one drop of Eosin-Nigrosin stain was mixed with a small drop of semen on a pre-warmed slide. After smearing it was placed on microscope and counted under 40x. After staining with Rose-Bengle Stain, the slide was observed for normal sperm count and spermatozoa measurement. The sperm was measured for head length and heat breadth with the help of micrometer fitted with eye piece of compound microscope. All values relating to semen evaluation parameter were expressed as mean \pm standard error (SE). One-way ANOVA test was performed to obtain the difference in volume per ejaculate, mass motility, sperm concentration, live sperm and normal sperm percentage. Correlation analysis was performed to find the relationship between non-return rate with different semen evaluation parameters. All statistical analysis was performed using SPSS (Statistical Package for Social Sciences) in window package.

\section{Results and Discussion}

\section{Volume of semen}

Mean value of ejaculate was found to be ranged between 2.58 to $4.01 \mathrm{ml}$ and difference among the bulls was significant $(\mathrm{P}<0.01)$. The volume of ejaculate differed significantly $(\mathrm{P}<0.01)$ among the bulls (Table 1). Highest volume per ejaculate $(4.01 \pm 0.14)$ was found in Holstein cross bull and the lowest volume $(2.58 \pm 0.07)$ was found in Red Chittagong bull. The differences in semen volume among the bulls might be due to random effect or due to breed effect. Effect could not be separated due to absence of replication/ of bulls of different breeds/ types used. Raju and Rao (1982) also reported a significant $(\mathrm{P}<0.01)$ breed difference in volume of semen. 


\section{Mass motility}

The average mass motility (\%) in fresh ejaculate was ranged between 52 and 65 . Analysis of variance revealed that bull to bull variation was significant $(\mathrm{P}<0.01)$ in motility of fresh semen (Table 1). Bratton et al. (1954) reported average mass motility of bovine fresh semen as $63.3 \%$ and the range was $50-80 \%$ which was almost similar to that of present study. These observations also do agree with the previous studies of Hoque et al. (1997) and Lasely (1951). The variation of motility in this study might be due to age, breed or random effect associated with the individual bulls.

Table 1. Evaluation of fresh semen as affected by individual bull

\begin{tabular}{|c|c|c|c|c|c|}
\hline Bull number & $\begin{array}{l}\text { Volume } \\
\text { (ml) }\end{array}$ & $\begin{array}{c}\text { Mass } \\
\text { motility (\%) }\end{array}$ & $\begin{array}{c}\text { Sperm } \\
\text { concentration } \\
(\times 106 / \mathrm{ml})\end{array}$ & $\begin{array}{c}\text { Live sperm } \\
(\%)\end{array}$ & $\begin{array}{c}\text { Normal sperm } \\
(\%)\end{array}$ \\
\hline Holstein cross (14) & $3.16^{\mathrm{a}} \pm 0.14$ & $62.50^{\mathrm{a}} \pm 0.83$ & $1028.00^{\mathrm{a}} \pm 41.55$ & $86.60^{\mathrm{a}} \pm 0.75$ & $90.00^{\mathrm{a}} \pm 0.60$ \\
\hline Holstein cross (129) & $4.01^{\mathrm{a}} \pm 0.14$ & $65.00^{\mathrm{a}} \pm 1.05$ & $975.00^{\mathrm{a}} \pm 25.96$ & $84.70^{\mathrm{a}} \pm 0.91$ & $88.50^{\mathrm{a}} \pm 0.91$ \\
\hline Sindhi cross (122) & $3.47^{\mathrm{b}} \pm 0.17$ & $64.00^{\mathrm{a}} \pm 1.45$ & $959.00^{\mathrm{a}} \pm 24.61$ & $84.00^{\mathrm{a}} \pm 0.99$ & $87.20^{c} \pm 0.73$ \\
\hline Sahiwal cross (143) & $3.34^{\mathrm{b}} \pm 0.16$ & $63.5^{\mathrm{a}} \pm 1.50$ & $940.00^{\mathrm{a}} \pm 25.82$ & $83.60^{\mathrm{a}} \pm 1.18$ & $87.00^{c} \pm 0.84$ \\
\hline Red Chittagong (45) & $2.81^{\mathrm{c}} \pm 0.08$ & $54.00^{\mathrm{b}} \pm 1.45$ & $764.50^{b} \pm 10.94$ & $78.10^{b} \pm 0.60$ & $82.20^{\mathrm{b}} \pm 0.66$ \\
\hline Red Chittagong (41) & $2.58^{\mathrm{c}} \pm 0.07$ & $52.00^{\mathrm{b}} \pm 1.53$ & $739.00^{\mathrm{b}} \pm 10.56$ & $74.7^{\mathrm{b}} \pm 1.00$ & $80.20^{\mathrm{b}} \pm 1.32$ \\
\hline Average & $3.23 \pm 0.08$ & $60.17 \pm 0.85$ & $900.92 \pm 17.34$ & $81.95 \pm 0.65$ & $85.85 \pm 0.57$ \\
\hline Level of significance & $* *$ & $* *$ & $* *$ & $* *$ & $* *$ \\
\hline
\end{tabular}

\section{Sperm concentration}

Sperm concentration differed significantly between bulls. However, ejaculates from Red Chittagong bulls did have significantly lower number of spermatozoa per $\mathrm{ml}$ compared to all other bulls encompassed in the study (Table 1). The results of present study support the findings of Hafez (1993) and Rao and Rao (1979). According to Hafez (1993), the concentration of bull semen ranges from $800-2000 \times 10^{6} / \mathrm{ml}$. Al-Hakim et al. (1984) postulated that variation in sperm concentration might be due to the difference in age, breed, collection frequency, feeding regime.

\section{Live sperm percentage}

In present study, lives sperm percentage ranged from 86.60-74.70. Analogical with other characteristics live sperm percentage was lower $(\mathrm{P}<0.01)$ in Red Chittagong bull in any bulls of any breed. Hahn et al. (1969) observed the average live sperm percentage for Holstein bull 83.5 and with a range from 70-90 which was almost similar to the average live sperm percentage of present study. The findings of present study collaborate with the results of Rao and Rao (1979) and Al-Hakim et al. (1984). The difference between breeds/crosses in live 
Bang. J. Anim. Sci. 2008, 37(2)

sperm percentage shows that performance of Red Chittagong bull was consistently lower than any other bull.

\section{Normal sperm percentage}

Morphologically normal sperm percentage of present study ranged from 80.20 to 90.00 (average $85.85 \pm 0.57)$. The significantly $(\mathrm{P}<0.01)$ highest percentage of normal sperm $(90 \pm$ 0.6) was found in Holstein cross (Bull No. 14). Normal sperm percentage in fresh semen varied significantly with an order of Holstein cross followed by Sindhi and Sahiwal cross and Red Chittagong bulls had lowest $(80.20 \pm 0.66,80.200 \pm 1.32)$ percentage compared to other bulls. The mean value was similar to the observation of Hahn et al. (1969) who obtained average normal spermatozoa percentage to be 85 and ranged from 75-95. The findings of the present study also collaborate with the results of Rao and Rao (1979).

\section{Morphometry of spermatozoa}

There was a significant $(\mathrm{P}<0.01)$ bull variation for head length and total length of spermatozoa (Table 2).In this study, significantly highest $(\mathrm{P}<0.01)$ head length of sperm was found in Holstein cross bulls followed by Red Chittagong Sindhi cross and Sahiwal cross bulls. But total spermatozoal length was significantly $(\mathrm{P}<0.01)$ lower in Red Chittagong bull than in other bulls. Head breadth of spermotozoa in bulls of all breeds/types behaved alike genetic group of bulls showed uniformity in spermatozoal measurement. Different measurements of bull spermatozoa in this experiment were in close agreements with the findings of Krajnc (1964) and Kuciel (1967).

Table 2. Morphometry of spermatozoa as affected by individual bull

\begin{tabular}{|l|c|c|c|}
\hline \multirow{2}{*}{\multicolumn{1}{|c|}{ Bull number }} & \multicolumn{3}{|c|}{ Spermatozoa measurements (micron) } \\
\cline { 2 - 4 } & Head length & Head breadth & Total length \\
\hline Holstein cross (14) & $10.55^{\mathrm{a}} \pm 0.09$ & $5.15 \pm 0.03$ & $74.43^{\mathrm{a}} \pm 0.08$ \\
Holstein cross (129) & $10.56^{\mathrm{a}} \pm 0.10$ & $5.13 \pm 0.03$ & $74.42^{\mathrm{a}} \pm 0.09$ \\
Sindhi cross (122) & $10.09^{\mathrm{c}} \pm 0.04$ & $5.09 \pm 0.03$ & $74.08^{\mathrm{a}} \pm 0.15$ \\
Sahiwal cross (143) & $10.06^{\mathrm{c}} \pm 0.03$ & $5.07 \pm 0.02$ & $74.03^{\mathrm{a}} \pm 0.15$ \\
Red Chittagong (45) & $10.16^{\mathrm{b}} \pm 0.01$ & $5.11 \pm 0.02$ & $73.41^{\mathrm{b}} \pm 0.10$ \\
Red Chittagong (41) & $10.15^{\mathrm{b}} \pm 0.03$ & $5.19 \pm 0.11$ & $73.28^{\mathrm{b}} \pm 0.06$ \\
\hline Average & $\mathbf{1 0 . 2 6} \pm \mathbf{0 . 0 3}$ & $\mathbf{5 . 1 3} \pm \mathbf{0 . 0 2}$ & $\mathbf{7 3 . 9 4} \pm \mathbf{0 . 0 7}$ \\
\hline Level of significance & $* *$ & NS & $* *$ \\
\hline
\end{tabular}

$* *=\mathrm{P}<0.01, \mathrm{NS}=$ Non significant $(\mathrm{P}>0.05)$

${ }^{a b c}$ Means with different superscripts within the same column differ significantly $(\mathrm{P}<0.05)$ from each other

\section{Non Return Rate (NRR) of Bulls}

The average 60 days non-return rate to insemination of various bulls is presented in Table 3 . The non-return rate over the breeds/types was affected by some semen evaluation 
parameters. Table 3 sharply shows that bulls with higher NRR did have superior quality semen although relations between them were not statistically established.

Table 3. Non Return Rate (\%) of bulls affected by some parameters of semen evaluation

\begin{tabular}{|c|c|c|c|c|c|}
\hline Bull No. & $\begin{array}{c}\text { No. of } \\
\text { observation }\end{array}$ & $\begin{array}{c}\text { Mass motility } \\
(\%)\end{array}$ & $\begin{array}{c}\text { Live sperm } \\
(\%)\end{array}$ & $\begin{array}{c}\text { Normal } \\
\text { sperm (\%) }\end{array}$ & NRR (\%) \\
\hline Holstein cross (14) & 115 & 62.5 & 86.6 & 90 & $\begin{array}{c}61.54 \\
\text { (36 months) }\end{array}$ \\
\hline Holstein cross (129) & 108 & 65 & 84.7 & 88.5 & $\begin{array}{c}62.75 \\
\text { (29 months) }\end{array}$ \\
\hline Sindhi cross (122) & 90 & 64 & 84 & 87.2 & $\begin{array}{c}62.29 \\
\text { (17 months) }\end{array}$ \\
\hline Sahiwal cross (143) & 75 & 63.5 & 83.6 & 87 & $\begin{array}{c}60.89 \\
\text { (24 months) }\end{array}$ \\
\hline Red Chittagong (45) & 65 & 54 & 78.1 & 82.2 & $\begin{array}{c}50.9 \\
(6 \text { months })\end{array}$ \\
\hline Red Chittagong (41) & 72 & 52 & 74.7 & 80.2 & $\begin{array}{c}45.62 \\
\text { (8 months) }\end{array}$ \\
\hline
\end{tabular}

Figures in parentheses indicate number of months respectively

Correlations between mass motility, live sperm and normal sperm percentage with non-return rate

Non-return rate was positively correlated with mass motility, live sperm percentage and normal sperm percentage of semen and the correlation co-efficient values were $0.97,0.94$ and 0.91 respectively (Fig. 1, 2 and 3). The findings of present study also agree with the results of Linford et al. (1976) and Hahn et al. (1969).

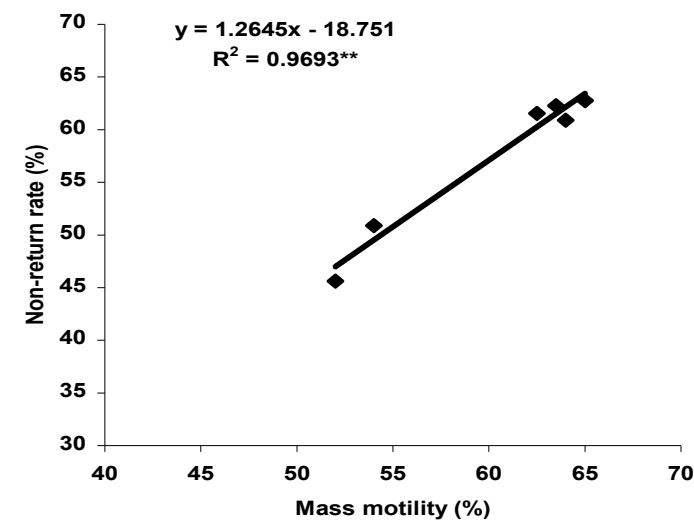

Fig. 1. Relationship of mass motility with non-return rate 


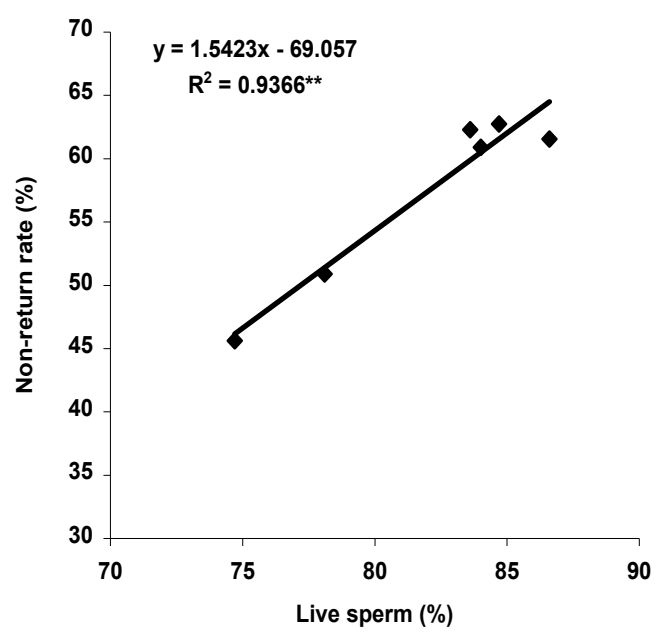

Fig. 2. Relationship of live sperm percentage with non return rate

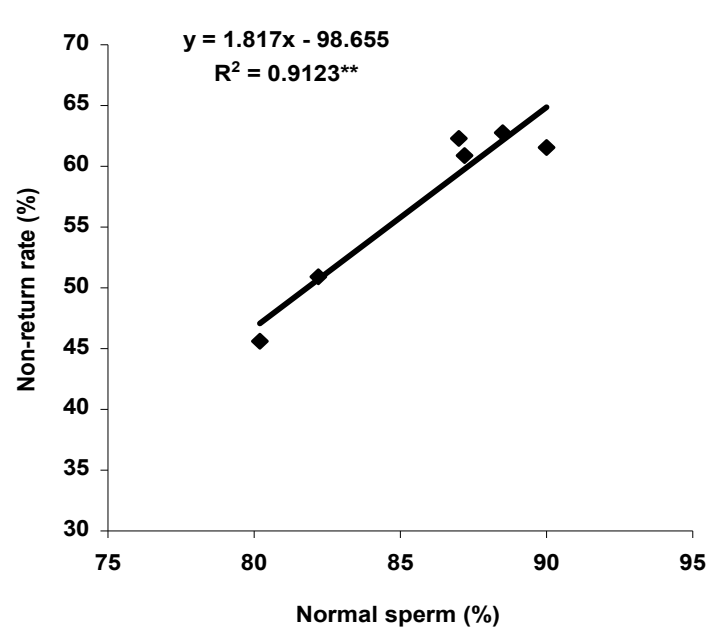

Fig. 3. Relationship of normal sperm percentage with non-return rate

\section{Conclusion}

From the above discussion it may be concluded that Holstein cross bulls ranked top and Red Chittagong bulls were found most inferior among the bulls under investigation. Semen quality associated with individual bull was evidently reflected on their non-return rate- a recognized measure of AI bull fertility.

\section{Literature Cited}

Al-Hakim, M. K., Ali, S. B. A. and Singh, B. P. 1984. Study on semen characteristics of Karadi (Kurdi) bulls. Indian J.Anim. Health. 23(2) : 163-169.

Bratton, R. W., Foote, R. H. and Henderson, C. R. 1954. The relationship between fertility and the number of spermatozoa inseminated. J. Dairy Sci. 37 : 1353-1356.

Hafez, E. S. E. 1993. Artificial insemination. In: Hafez ESE. (Ed), Reproduction in Farm Animals. Lea and Febiger, Philadelphia, pp. 424-439.

Hahn, J., Foote, R. H. and Seidel, G. E. 1969. Quality and freezability of semen from growing and aged dairy bulls. J. Dairy Sci. $52: 1843-1848$.

Herman, H. A. and Madden, F. W. 1963. The Artificial Insemination of dairy and beef cattle. A hand book of laboratory manual, Freeman and Company, San Francisco, USA. pp. 579-610.

Hoque, M. A., Amin, M. R. and Hussen, M. S. 1997. Breeding profiles of Sahiwal bulls and native cows in dairy pocket of Bangladesh. Bangladesh J. Anim. Sci. 26(1-2) : 147-153. 
Hoque, M. D. 1998. Phenotypic variation and repeatability of semen characteristics of purebred and Cross-bred bulls. M. Sc. Thesis. Department of Animal Breeding and Genetics, Bangladesh Agricultural University, Mymensingh.

Kranjc, A. 1964. Biometric studies on bull spermatozoa in relation to fertility. (A contribution to the problem of sex dimorphism of spermatozoa). Anim. Breed. Abstr. 33 : 1216.

Kuciel, J. 1967. The size of the sperm head in two lines of Red spotted bulls. Anim. Breed. Abstr. 36 : 1427.

Lasely, S F. 1951. Spermatozoa motility as measure of semen quality. J. Anim. Sci. $10: 21$.

Linford, E., Glover, F. A., Bishop, C. and Stewart, D. L. 1976. The relationship between semen evaluation methods and fertility in the bull. J. Reprod. Fertil. $47: 283-291$.

Raju, M. S. and Rao, A. R. 1982. Note on the semen characteristics of Cross-bred and purebred bulls. Indian J. Anim. Sci. 5(15) : 1230-1232.

Rao, T. L. N. and Rao, A. R. 1979. Fertility and its relationship with semen characteristics in Crossbred bulls. Indian Vet. J. $56: 33-36$.

Willett, E. L. and Salisbury, G. W. 1942. The effect of various diluters, cooling rate, temperature of storage and some other factors on the livability of spermatozoa in stored samples of bull semen. Cornell Univ. Agr. Expt. Stat. Manual. 249. 